\title{
Using actual and ultrasound carcass information in beef genetic evaluation programs
}

\author{
Joseph Keith Bertrand ${ }^{1}$ \\ ${ }^{1}$ Animal and Dairy Science Department - University of Georgia, Athens, GA USA 30602-2771.
}

ABSTRACT- Increased movement toward alliances and grid pricing in the U.S. has led to an increase interest in genetic values for carcass traits. The literature suggests that carcass genetic values are an effective tool to enhance selection for carcass traits, and that it is possible to select sires within a breed that can increase marbling score without adversely affecting external fat thickness or percent retail product relative to the breed mean. Ultrasound has been investigated as a cheaper means of collecting carcass information. The literature indicates that carcass traits measured via ultrasound on yearling seedstock will respond to selection. Although the literature is variable on the subject, there are reported genetic correlation $\left(\mathrm{r}_{\mathrm{g}}\right)$ estimates between live animal ultrasound and actual carcass attributes that are greater than .70 for all ultrasonically measured carcass traits. When $r_{g}$ between seedstock ultrasound and slaughter cattle carcass measures are $\geq 0.70$, similar or greater genetic progress in finished cattle carcass merit could be achieved by using ultrasound information entirely compared to using typical carcass progeny information; however, the maximum accuracy of prediction using ultrasound information in lieu of finished cattle carcass information would be $r_{g}$. Therefore both actual and live animal, ultrasonically measured carcass traits should be included in genetic evaluation programs, which will allow for an increase in the accuracy of prediction of carcass genetic values on young seedstock animals due to the inclusion of ultrasound information, and will also allow for the possible production of high accuracy sires based on finished cattle progeny carcass information. Multi-breed models are being developed to allow for the prediction of genetic values for carcass traits in populations composed of animals of varying breed composition.

Key Words: beef carcass traits, genetic evaluation, multi-breed models, ultrasound

\section{Uso de informações reais e de ultra-som de carcaças em programas de avaliação genéticas de bovinos de corte}

RESUMO - A tendência de formação de alianças e precificação nos Estados Unidos têm levado a um crescente interesse por valores genéticos para características de carcaça. A literatura sugere que valores genéticos de carcaça são uma ferramenta efetiva para incrementar a seleção para características de carcaça, e que é possível selecionar reprodutores dentro de uma raça que possam incrementar escores de marmoreio sem afetar adversamente a espessura de gordura de cobertura ou rendimento relativo a média da raça. O ultrassom tem sido investigado como um meio menos expencivo de coletar informações de carcaça. A literatura indica que medidas de características de carcaças viam ultrasson em animais jovens responderão a seleção. Embora a literatura seja variável sobre o assunto, existem estimativas de correlações genéticas ( $\mathrm{rg}$ ) entre medidas de ultrassom no animal vivo e atributos reais de carcaça superiores a 0,70 para todas as características medidas por ultrassom. Quando rg entre medidas de ultrassom em reprodutores e medidas de carcaça no animal ao abate são maiores ou iguais a 0,70 , similar ou maior progresso genético na qualidade de carcaças de bovinos terminados poderiam ser obtidos pelo uso de informações de ultrassom comparado ao uso informações das carcaças das progênies, contudo, a máxima acurácia das predições usando informações de ultrassom em vez de informações de carcaças de animais terminados seria a rg. Portanto ambos, medidas reais e de ultrassom poderiam ser incluídas em programas de avaliação genética, os quais permitirão um aumento na acurácia das predições dos valores genéticos de touros jovens devido a inclusão de informações de ultrassom e também seria possível produzir informações altamente acuradas para touros baseado em informações de progênies terminadas. Modelos multirraciais estão sendo desenvolvidos para permitir a predição de valores genéticos para características de carcaça em populações compostas de animais com diferentes contribuições raciais.

Palavras-chave: características de carcaça de bovinos de corte, avaliação genética, ultrassom, modelos multirraciais 


\section{Introduction}

Many U.S. breed associations, producers, feeders, packers, and retailers have formed cooperative agreements (alliances) to develop programs that produce cattle that hit specified targets where carcasses are individually priced on a grid or formula that is usually based on some combination of quality grade (a measure of palatability determined by age and marbling), yield grade (a measure of cutability), and carcass weight. Producers and feeders that participate in these alliances are usually paid a base price for cattle that hit the target, with premiums and discounts for cattle that exceed or fail to meet, respectively, the target specifications.

Due to the industry $=\mathrm{s}$ need for genetic information in this era of grid pricing and alliances, many U.S. beef breed associations are providing genetic values for important carcass traits. Most breed associations collect carcass information from finished, slaughter cattle and live animal ultrasound measures from seedstock cattle to use in their genetic evaluation programs for carcass traits. The purpose of this paper is 1) to briefly present some information on the usefulness of carcass genetic values, 2) to provide information of the usefulness of live animal ultrasound measures on seedstock as a vehicle to collect information for carcass evaluation, and 3) to provide some information on the prediction of multi-breed genetic values for carcass traits.

Using carcass genetic values to select for carcass traits

Many U.S. beef breed associations provide carcass genetic values to enhance selection for carcass traits. The main carcass traits that are considered in evaluation programs are carcass weight, ribeye muscle (longissimus dorsi) area measured between the 12-13th rib, external backfat thickness measured between the 12-13th rib, and marbling score, which is measured in the ribeye muscle and is a subjective measure of intramuscular fat. These carcass measures are primarily obtained on steers and heifers finished in feedlots and slaughtered between 15-17 months of age, and usually carcass traits are adjusted to an age constant basis. Bertrand et al. (2001) provided a review of carcass parameter estimation studies conducted from 1980 to 2000 and reported that the average heritabilities for carcass weight, carcass ribeye area, carcass backfat thickness and carcass marbling score adjusted to an age constant basis, were between .34 to .46 . Rios-Ultrera et al. (2005) analyzed carcass measures from 1,664 steers of varying breed composition and reported heritability estimates for carcass weight, ribeye area, backfat thickness, and marbling score adjusted to an age constant basis were .27 “.08, 24 “.07,.20“.07, and .40 “. 09 , respectively. It is obvious from the literature that sufficient additive variation exists to provide genetic change for carcass traits through selection programs.

Producers are very interested in the ability to select for decreased external fat thickness or increased retail yield and growth without adversely affecting marbling score. Bertrand et al. (2001) found that genetic correlations averaged across studies between marbling score-ribeye area, marbling score-backfat thickness, and marbling scorepercent retail product were $-.01, .10$ and -.28 , respectively. Rios-Ultrera et al. (2005) reported that, when traits were adjusted to an age constant basis, that the correlations between marbling score-ribeye area, marbling score-backfat thickness, and marbling score-percent retail product were -.06 “. $09, .19$ “.08 and -.24“.08, respectively. Even though some of these correlations are antagonistic, the small magnitudes of the correlations suggests that it may be possible to use predicted carcass genetic values to increase marbling within a breed without increasing fat thickness or decreasing percent retail product. Vieselmeyer et al. (1996) and Bertrand et al. (1997) reported results from selection studies that showed Angus marbling and fat thickness EPD could be used to select sires to produce progeny that have increased marbling scores without increased subcutaneous fat. Results from the 2009 Angus Sire Summary (AAA, 2009) shows that from 1980 to 2007, the Angus breed has made positive genetic trend for weaning weight and yearling weight and at the same time, has made positive genetic trend for marbling score. Both the literature and current observational evidence show that carcass genetic values from a national genetic evaluation program can be used effectively to improve marbling score without an increase in external fat thickness or a decrease in growth.

The use of ultrasound for the prediction of carcass genetic values

The number of carcass records for most breeds is small compared to other traits such as birth, weaning, and yearling weight, scrotal circumference, and calving ease due to the cost of data collection and difficulty in collecting carcass information. Ultrasound has been investigated as a potential cost effective vehicle to collect live animal carcass measures on yearling seedstock. Moser (1997) estimated that the average cost per progeny for a test sire participating in a breed association sponsored carcass progeny testing program was $\$ 97$, while the average cost per animal to collect carcass data was estimated at $\$ 17$, assuming 100 animals were measured and the technician $=$ s travel distance was $403 \mathrm{~km}$. Even though this report was provided a decade 
ago, the relative costs of collecting ultrasound information compared to carcass progeny testing program information has not appreciably changed; therefore, ultrasound remains a cost effective method to collect carcass information.

Reports have shown that ultrasound technology can be used to measure ribeye area, external fat thickness, and percent intramuscular fat with acceptable precision (Robinson et al., 1992, Herring et al., 1998, Wilson et al., 1998, and Greiner et al., 2003). However, it is not enough that ultrasound can accurately measure carcass traits on the live animal; it must be shown that live animal carcass measures taken on breeding seedstock can be used in genetic evaluation programs to predictably change carcass traits in finished cattle. Table 1 contains heritability estimates for live animal, ultrasound measures of ribeye area, external $12-13^{\text {th }}$ rib fat thickness, and percent intramuscular fat. The estimates in this table were from data on yearling seedstock, mainly bulls, adjusted to either 365 or $400 \mathrm{~d}$ of age, that came from relatively large populations of field data, and that were from analyses conducted in the last 10 years. The heritability estimates for ribeye area, external backfat, and percent intramuscular fat on yearling bulls measured via ultrasound were similar in magnitude to the heritabilities of the counterpart carcass trait measured in slaughter steers. The average magnitude for all three heritabilites was $\geq .30$, which indicates that all three traits should respond to selection.

Table 2 provides genetic correlations between yearling (365 to $400 \mathrm{~d}$ ) seedstock ultrasound measures of carcass traits and similar traits measured in finished cattle slaughtered between 15-17 months of age. The reports are somewhat variable, but the genetic correlations between the carcass traits measured via ultrasound on seedstock cattle with the corresponding carcass trait measured in slaughter cattle were all $>.50$ with an average estimate close to .70 . Sapp et al. (2002) conducted a study in which different pairs of Angus bulls were selected from three cooperator herds in Georgia, USA. The bull pairs were selected to create large differences based on their age adjusted phenotypic yearling percent intramuscular fat performance within the same contemporary group. Each year the bulls were randomly mated to between 14 to 30 commercial Angus females, and the resulting steer progeny were backgounded, then sent to a commercial feedlot, and slaughtered at an average of approximately 480 days of age. Steer progeny from sires with high phenotypic percent intramuscular fat measures had higher adjusted marbling scores $(P<.05)$ and quality grades $(P<.05)$ than steer progeny from sires with low phenotypic intramuscular fat percent measures. The live animal ultrasound data from all bulls measured in the cooperator herds was combined with other ultrasound records collected by the American Angus Association. Genetic values (expected progeny differences, EPD) were then computed using all available information after adjusting bull ultrasound measurements to 365 days, and heifer ultrasound measurements to 390 days and to a bull equivalent. The regression of age adjusted carcass marbling score of the steer progeny on the ultrasound percent intramuscular fat EPD of the sires produced a highly significant regression coefficient of .905. This regression coefficient meant that for every $1.0 \%$ unit difference in sire intramuscular fat percent EPD, a corresponding difference of a little more than $9 / 10$ of a marbling score was observed in the steer progeny. The information from this study demonstrated that young animal ultrasound intramuscular fat percent measures can be used to provide EPD on yearling bulls that can be used as a selection tool to enhance marbling score in future steer offspring.

In order to relate the potential cost effectiveness of using ultrasound measures versus carcass cooler measurements, the following example using parameters used by the International Brangus Breeders Association (IBBA) as a part of their 2009 genetic evaluation program is provided. The estimates for the phenotypic SD (ó ${ }_{\mathrm{P}}$ ) and heritability, respectively, for seedstock ultrasound ribeye area were $7.59 \mathrm{~cm}^{2}$ and .30 , for 12-13th rib fat thickness were $.15 \mathrm{~cm}$ and .35 , and for percentintramuscular fat were $.71 \%$ and .19 . The estimates for the phenotypic standard deviation and heritability, respectively, for slaughter cattle ribeye area were $7.45 \mathrm{~cm}^{2}$ and .33 , for fat thickness were $.39 \mathrm{~cm}$ and .29 , and for marbling score were 65.07 and .33. The amount of expected genetic change per generation for a typical progeny testing program based on slaughter cattle information can be estimated according to Falconer (1981):

$$
\Delta G=1 / 2 i_{m} h^{2} \sigma_{p} \sqrt{\frac{n}{4+(n-1) h^{2}}}+1 / 2 i_{f} h^{2} \sigma_{p} \sqrt{\frac{n}{4+(n-1) h^{2}}}
$$

An estimate of $3.02 \mathrm{~cm}^{2}, .14 \mathrm{~cm}$ and 26.4 score units of genetic change per generation $(\Delta G)$ for ribeye area, fat thickness, and marbling score, respectively, was produced from the application of the above equation by using the provided parameters and assuming selection intensities for males $\left(i_{m}\right)$ of 1.76 (top $10 \%$ selected) and for females $\left(i_{f}\right)$ of 0 and $20(n)$ progeny per sire. Assuming that a progeny testing program is conducted using only live animal, ultrasound measures on yearling seedstock, where the price ratio of gathering a carcass progeny record to an 
Table 1 - Heritability estimates for age-adjusted live animal ultrasound measures on seedstock cattle

\begin{tabular}{lccc}
\hline & \multicolumn{2}{c}{ Trait } \\
\cline { 2 - 4 } Source & Ribeye area & $12-13^{\text {th }}$ rib fat thickness & Intramuscular fat \% \\
\hline Devitt \& Wilton (2001) & .48 & .52 & .23 \\
Unpub. Anal. of Int. Brangus Breeders Assoc. Field Data (2002) & .30 & .35 & .19 \\
Crews et al. (2003) & .37 & .53 & .47 \\
Unpub. Anal. of Amer-Int. Charolais Assoc. Field Data (2003) & .46 & .35 & .23 \\
MacNeil \& Northcutt (2008) & .33 & .39 & .38 \\
Average & .39 & .43 & \\
\hline
\end{tabular}

Table 2 - Genetic correlation estimates between 365-day seedstock live animal ultrasound and 15-16 month carcass traits in slaughter cattle

\begin{tabular}{|c|c|c|c|}
\hline \multirow[b]{2}{*}{ Source } & \multicolumn{3}{|c|}{ Trait combination } \\
\hline & UREA-CREA $^{\mathrm{a}}$ & UFAT-CFAT & UIMF-CMARB \\
\hline Devitt \& Wilton (2001) & .66 & .88 & .80 \\
\hline Unpub. Anal. of Int. Brangus Breeders Assoc. Field Data (2002) & .89 & .69 & .70 \\
\hline Crews et al. $(2003)^{\mathrm{b}}$ & .80 .54 & .79 .83 & .74 .69 \\
\hline Unpub. Anal. of Amer-Int. Charolais Assoc. Field Data (2003) & .79 & .71 & .68 \\
\hline MacNeil \& Northcutt $(2008)^{b}$ & .63 .78 & .53 .55 & .66 .52 \\
\hline Average & .72 & .71 & .68 \\
\hline
\end{tabular}

${ }^{\text {a }}$ UREA and CREA = ultrasound and carcass measures of ribeye area from yearling seedstock (ultrasound) or from slaughter cattle (carcass); UFAT and CFAT = ultrasound and carcass measures of backfat thickness from yearling seedstock (ultrasound) or slaughter cattle (carcass); UIMF = percent intramuscular fat measures from seedstock cattle; CMARB = marbling score measures from slaughter cattle.

${ }^{\mathrm{b}}$ First estimates are from ultrasound measures from yearling bulls; second estimates are from ultrasound measures from yearling heifers.

ultrasound progeny record is5, the selection intensity for males is 1.76 and for females is .80 (top $50 \%$ selected), the number of ultrasound measured progeny per sire that could be tested at the same cost as collecting 20 actual carcass measures would be 100 . Because seedstock females can also be also evaluated, the number of ultrasound progeny per female used in the comparison was 3 . The correlated response in actual carcass traits by selection based on ultrasound traits could be computed by $\Delta \mathrm{G}($ carcass trait $)=\Delta \mathrm{G}($ ultrasound trait $) * \mathrm{r} * \sigma_{\mathrm{AC}}{ }^{\prime}$ $\sigma_{\mathrm{AU}}$, where $\mathrm{r}$ is the genetic correlation between the ultrasound and carcass trait and $\sigma_{\mathrm{AC}}$ and $\sigma_{\mathrm{AU}}$ are the additive genetic standard deviations for the carcass and ultrasound trait, respectively (Falconer, 1981). Genetic correlations of $.70, .67$ and .75 between carcass and ultrasound ribeye area, fat thickness and marbling (\% intramuscular fat), respectively, would be required for a progeny testing program based solely on ultrasound progeny measures to yield the same single trait selection genetic progress at the same cost of a typical carcass progeny testing program where 20 progeny per sire were collected. For the above example, the actual genetic correlation requirements are probably lower since individual ultrasound measures would also be available on the seedstock sires and dams. As seen in table 2, the average genetic correlations between the ultrasound seedstock measures and the corresponding carcass measures were all close to .70. Therefore, the research strongly suggests that ultrasound measurements of breeding animals may be used in genetic evaluation programs to reduce the time and expense required to obtain useful estimates of genetic merit for carcass traits.

Because the genetic correlations between carcass and ultrasound measures do not appear to be unity, the best opportunity to benefit from these favorable relationships is to combine seedstock ultrasound and finished cattle carcass traits in multiple-trait models. Crews et al. (2004) concluded that a genetic evaluation that combined actual and live animal measures of carcass traits using models that treated actual and live animal measures as different traits provided more accurate genetic values for carcass traits for a larger sample of animals compared to genetic evaluations that predicted carcass genetic values using only live animal or carcass data alone. MacNeil \& Northcutt (2008) concluded that a genetic evaluation for carcass traits that combined carcass measurements from slaughter animals and live animal ultrasound carcass measures from seedstock cattle using multi-trait models that treated actual carcass measures and live animal ultrasound measures as different traits appropriately weights the information from both sources and provides breeders carcass genetic values that can enhance their selection decisions. If the genetic correlations between seedstock ultrasound and finished cattle carcass measures are high, it may be that carcass 
genetic evaluation programs could rely solely on ultrasound measures for the computation of genetic values to improve finished cattle carcass traits, but the accuracy of the genetic values for any animal predicted using only ultrasound seedstock measures would never be greater than the genetic correlation between the ultrasound seedstock and finished carcass measures. Relative to programs that use only actual carcass information or only ultrasound information, combining these two sources of information allows for an increase in the accuracy of prediction of carcass genetic values on young seedstock animals due to the inclusion of ultrasound information and also allows for the possible production of high accuracy sires based on finished cattle progeny carcass information. Continued research needs to be conducted to quantify genetic relationships between ultrasound and actual carcass measures within other populations (breeds), across different ages of cattle, and at different amounts of finish in order to determine which management regimes and measurement ages produce the highest genetic correlations between seedstock and slaughter cattle.

Multi-breed genetic evaluation for carcass traits multibreed genetic evaluation for carcass traits

Because many U.S. producers use crossbreeding in their programs, there has been an interest in the U.S. beef industry for the prediction of across-breed genetic values. Elzo and Famula (1895) and Arnold et al. (1992) have proposed models for the genetic evaluation of multi-breed populations. However as shown by Rodriguez-Almeida, the separation of direct and maternal breed effects, even for simple models, requires data from a variety of crosses. It may be extremely difficult to achieve a data structure across a number of different herds that will allow the estimation of all the additive and non-additive breed effects directly from the growth and carcass information collected by breeders and producers. Notter and Cundiff (1991) proposed an approach that used estimated sire breed differences obtained from a long-term breed evaluation research project after correcting the breed differences for sampling and genetic trends. This method, with some slight changes over time, has been used to produce breed adjustment factors that can be added to expected progeny differences (predicted transmitting abilities) to produce genetic values to compare animals of different breeds. This method has been used since 1993 to provide breed adjustment factors for birth, weaning and yearling weight and maternal milk (Cundiff, L.V., 1993). Van Vleck et al. (2007) provided results when this methodology was used to estimate across-breed adjustment factors for carcass traits.
Klei et al. (1996) proposed using a Bayesian approach that employs an appropriate animal model for the analysis of multi-breed information and combines prior literature estimates of breed and heterosis effects with data to provide across-breed genetic values. This approach weights the literature information relative to the data in order to estimate breed and heterosis effects. When the data does not allow the estimation of a particular breed or heterosis effect, the literature value will serve as the estimate. However when data is present to estimate a breed or heterosis effect, the estimated effect is a combination of both data and prior literature information, and the prior literature values will receive less consideration (weight) as more actual data is available to estimate the breed effects. This approach can be applied to field data sets that contain animals of varying breed combinations to compute multi-breed genetic values. Legarra et al. (2007) presented results from the application of this technology for the estimation of growth traits and birth weight in a data set provided by a U.S. beef breed association. The American Simmental Association employs this methodology to provide genetic values for growth traits and carcass traits (ASA, 2009).

Two possibilities exist for including ultrasound carcass information on seedstock animals in a multi-breed evaluation. One is to use the ultrasound information nested within purebred breed type to allow for a better prediction of the genetic values of animals nested within each breed. This approach would not allow the use of live animal ultrasound measures on crossbred seedstock. Another approach would be to construct breed and heterosis tables for live animal ultrasound measures of carcass traits and use them as priors for estimates of breed and heterosis effects for live animal ultrasound carcass traits in the multi-breed evaluation. This approach would allow for ultrasound measures on crossbred seedstock to be directly utilized in the multi-breed evaluation. However, very few studies have been conducted that provide breed comparisons for ultrasound carcass trait information on young bulls and heifers. Therefore, the only way to construct a prior breed effect table for ultrasound traits would be to use an ad hoc procedure that assumes that the only differences between the ultrasound breed effects and the carcass breed effects are due to sex and variance scaling effects. The multi-breed genetic evaluation for carcass traits employed by the American Simmental Association employs this latter approach and includes tables for actual and for ultrasonically measured carcass traits. Research needs to be conducted to discern which multi-breed evaluation approach provides the most accurate evaluation. 


\section{Implications}

The scientific literature suggests that predicted genetic values can be an effective tool to enhance selection for carcass traits. Several studies have reported moderate to high genetic relationships between carcass measures collected on young seedstock via ultrasound and carcass measures collected on slaughter cattle; therefore, consideration should be given to the use of ultrasound measures to supplement traditional slaughter carcass measures in genetic programs. Also, multi-breed models are being explored to allow the prediction of genetic values for carcass traits in populations composed of animals of varying breed composition.

\section{Literature Cited}

AAA [2009]. Angus sire evaluation report. St. Joseph: American Angus Association. Disponível em: <http://www.angus.org/ sireeval/index.html. Acesso em: 28/3/2009.

AAA [2009]. Simmental sire evaluation report. Bozeman: American Simmental Association. Disponível em:<http:// w w w . s i m me n t a 1 . org/u s e r i mage s/ Sire\%20Summary\%20Spring\%2009.pdf Acesso em: 28/3/2009.

ARNOLD, J.W.; BERTRAND, J.K.; BENYSHEK, L.L. Animal model for genetic evaluation of multi-breed data. Journal of Animal Science, v.70, p.3322-3332, 1992.

BERTRAND, J.K.; GREEN, R.D.; HERRING, W.O. et al. Genetic evaluation for beef carcass traits. Journal of Animal Science, v.70(E. Suppl.), p.E190-E200, 2001.

BERTRAND, J.K.; MOSER, D.W.; HERRING, W.O. Selection for carcass traits. Dickinson: Beef Improvement Federation Research Symposium Annual Meeting, 1997. p.93-89.

CREWS, JR., D.H.; POLLAK, E.J.; QUAAS, R.L. Evaluation of Simmental carcass EPD estimated using live and carcass data. Journal of Animal Science, v.82, p.661-667, 2004.

CREWS, JR., D.H.; POLLAK, E.J.; WEABER, R.L. et al. Genetic parameters for carcass traits and their live animal indicators in Simmental cattle. Journal of Animal Science, v.81, p.1427$1433,2003$.

CUNDIFF, L.V. Breed comparisons adjusted to a 1991 basis using current. Asheville: Beef Improvement Federation Research Symposium Annual Meeting, 1993. p.9114-123.

DEVITT, C.J.B.; WILT ON, J.W. Genetic correlation estimates between ultrasound measurements on yearling bulls and carcass measurements on finished steers. Journal of Animal Science, v.79, p.2790-2797, 2001.

ELZO, M.A.; FAMULA, T.R. Multi-breed sire evaluation procedures with a country. Journal of Animal Science, v.60, p.942-
952, 1985.

FALCONER, D.S. Introduction to quantitative genetics. 2.ed. Essex: Longman Group Limited, 1981.

GREINER, S.P.; ROUSE, GH.; WILSON, D.E. et al. The relationship between ultrasound measurements and carcass fat thickness and longissimus muscle area in beef cattle. Journal of Animal Science, 2003 81: 676 682, 2003.

HERRING, W.O.; KRIESE, L.A.; BERTRAND, J.K. et al. Comparison of four real-time ultrasound systems that predict intramuscular fat in beef cattle. Journal of Animal Science, v.76, p.364-370, 1998

KLEI, L.R.L.; QUAAS, E.J.; POLLAK, B.E. Multiple breed evaluation. Birmingham: Beef Improvement Federation Research Symposium Annual Meeting, 1996. p.106-113.

LEGARRA, A.; BERTRAND, J.K.; STRABEL, T. et al. Multibreed genetic evaluation in a Gelbvieh population. Journal of Animal Breeding Genetic, v, 124, p.286-295, 2007.

Mac NEIL, M.D.; NORT HCUTT, S.L. National cattle evaluation system for combined analysis of carcass characteristics and indicator traits recorded by using ultrasound in Angus cattle. Journal of Animal Science, v.86, p.2518-2524, 2008.

MOSER, D.W. Use of yearling ultrasound measurements of breeding cattle to predict breeding values for carcass traits. 1997. Ph.D. (Dissertation) - University of Georgia, Athens.

ROBINSON, D.L.; McDONALD, C.A.; HAMMOND, K. et al. Live animal measurement of carcass traits by ultrasound: assessment and accuracy of sonographers. Journal of Animal Science, v.70, p.1667-1676, 1992.

RODRIGUEZ-ALMEIDA, F.A.; Van VLECK, L.D.; GREGORY, K.E. Estimation of direct and maternal breed effects for prediction of expected progeny differences for birth and weaning weights in three multi-breed populations. Journal of Animal Science, v.75, p.1203-1212, 1997.

SAPP, R.L.; BERTRAND, J.K.; PRINGLE, T.D. et al. Effects of selection for ultrasound intramuscular fat percentage in Angus bulls on carcass traits of progeny. Journal of Animal Science, v.80, p.2017-2022, 2002

RIOS-UTRERA, A.; CUNDIFF, L.V.; GREGORY, K.E. et al. Genetic analysis of carcass traits of steers adjusted to age, weight or fat thickness slaughter endpoints. Journal of Animal Science, v.83, p.764-776, 2005.

Van VLECK, L.D.; CUNDIFF, L.V.; WHEELER, T.L. et al. Across-breed adjustment factors for expected progeny differences. Journal of Animal Science, v.85, p.13691376, 2007.

VIESELMEYER, B.A.; RASBY, R.J.; GWARTNEY, B.L. et al. Use of expected progeny differences for marbling in beef: I. Production traits. Journal of Animal Science, v.74, p.1009-1013, 1996.

WILSON, D.E., GRASER, H.-U.; ROUSE, GH. et al. 1998. Prediction of carcass traits using live animal ultrasound. In: WORLD CONGRESS OF GENETIC APPLIED LIVESTOCK PRODUCTION, 6., s.d., 1998. Proceedings... s.d.: 1998. v.23, p.61-68. 